\title{
Modeling Research Competency of Faculty Member : A Preliminary Data
}

\author{
Mery Citra Sondaria,b* , Jann Hidajat Tjakraatmadjaa , Yuni Ros Bangun ${ }^{a}$ \\ ${ }^{a}$ School of Business and Management, Institut Teknologi Bandung, Indonesia \\ ${ }^{b}$ Department of Management and Business, Faculty of Economics and Business, Universitas Padjadjaran, Indonesia \\ *Corresponding author: mery.citra@sbm-itb.ac.id
}

\begin{abstract}
Research productivity of higher education institutions (HEIs) in Indonesia lags behind those in other countries in the region, that implicates their reputation. Because in aggregation, research productivity of HEI is the productivity of its faculty members, thus research competency of faculty members might be the factors that cause the low research productivity of those HEIs in Indonesia. Focusing on Faculty economics and Business, this paper aims to develop the model of research competency for faculty member. This paper show the analytical process used by author in modeling research competency using behavioral event interview (BEI). The preliminary data used in this paper consist of two subjects, the effective and outstanding performer, out of minimum seven respondents that have been targeted. The findings reveal that outstanding performer tend to show more people-focused behavior than task-focused behavior. It is consistent with the previous studies of competency modeling for professional / knowledge workers.
\end{abstract}

Keywords : Research competency; competency model; behavioral event interview (BEI)

(C) 2016 Penerbit UTM Press. All rights reserved

\subsection{INTRODUCTION}

This paper is written based on author's concern on the fact that research productivity of higher education institutions (HEIs) in Indonesia lags behind those in other countries in the region, such as Malaysia, Singapore and Thailand. Because most international ranking agencies (one of them, is Quacquarelli Symonds-QS, based in London), put high weight on research indicators (Buela-Casal, et.al,2006), thus, low level of research productivity of HEIs in Indonesia affect their reputation, which are seen from the rank of those HEIs among other international HEIs (see table.1).

Table 1 Comparison between Country-level research productivity ranks, HEIs- level research productivity rank and HEIs ranking.

\begin{tabular}{|c|c|c|c|c|}
\hline Higher Education Institution (Country) & $\begin{array}{l}\frac{\text { National- }}{\text { wide HEI's }} \\
\frac{\text { ranking }}{}\end{array}$ & $\begin{array}{c}\text { Total documents } \\
\text { per February } \\
2014 \\
\end{array}$ & $\begin{array}{c}\text { Avrg per } \\
\text { year (2011- } \\
2013)\end{array}$ & $\begin{array}{l}\text { QS World } \\
\text { ranking } \\
\text { (Sept 2013) }\end{array}$ \\
\hline National University of Singapore (Singapore) & 1 & 80,454 & $5,607.7$ & 24 \\
\hline Nanyang Technological University (Singapore) & 2 & 48,856 & $4,605.3$ & 41 \\
\hline University of Malaya (Malaysia) & 1 & 23,864 & $2,922.0$ & 167 \\
\hline Mahidol University (Thailand) & 1 & 21,470 & $1,585.0$ & 283 \\
\hline Universiti Sains Malaysia (Malaysia) & 2 & 18,880 & $2,619.7$ & 355 \\
\hline Universiti Putra Malaysia (Malaysia) & 3 & 18,396 & $2,721.3$ & $411-420$ \\
\hline Institut Teknologi Bandung (Indonesia) & 1 & 3,394 & 494.3 & $461-470$ \\
\hline University of Indonesia (Indonesia) & 2 & 2,973 & 343.0 & 309 \\
\hline Gadjah Mada University (Indonesia) & 3 & 1,707 & 197.0 & $501-550$ \\
\hline
\end{tabular}

After all, because research productivity of higher education institution (HEI) is the aggregate number of research conducted by its faculty member (Ju, 2010), thus, research productivity of HEI also reflects the performance of its faculty member (Hesli \& Lee, 2011; Kotrlik, Bartlett, Higgins, \& Williams, 2002). Low level of performance might be caused by the lack of ability. In this case, the ability of faculty members are correlated with level of education. Recapitulation data of higher education database (PDPT =Pangkalan Data Perguruan Tinggi) from Directorate General of Higher Education (Dikti), reveal that education level of faculty member of higher education institution in Indonesia ranging from 2-year diplomme to doctorate, and majority have already had master degree. Since doctorate program is believed as the substantial training for developing research competency (Byrne \& Keefe, 2002), From figure 1. we can assume that only 12\% of faculty members in Indonesia that have already occupied with such capability of research. 


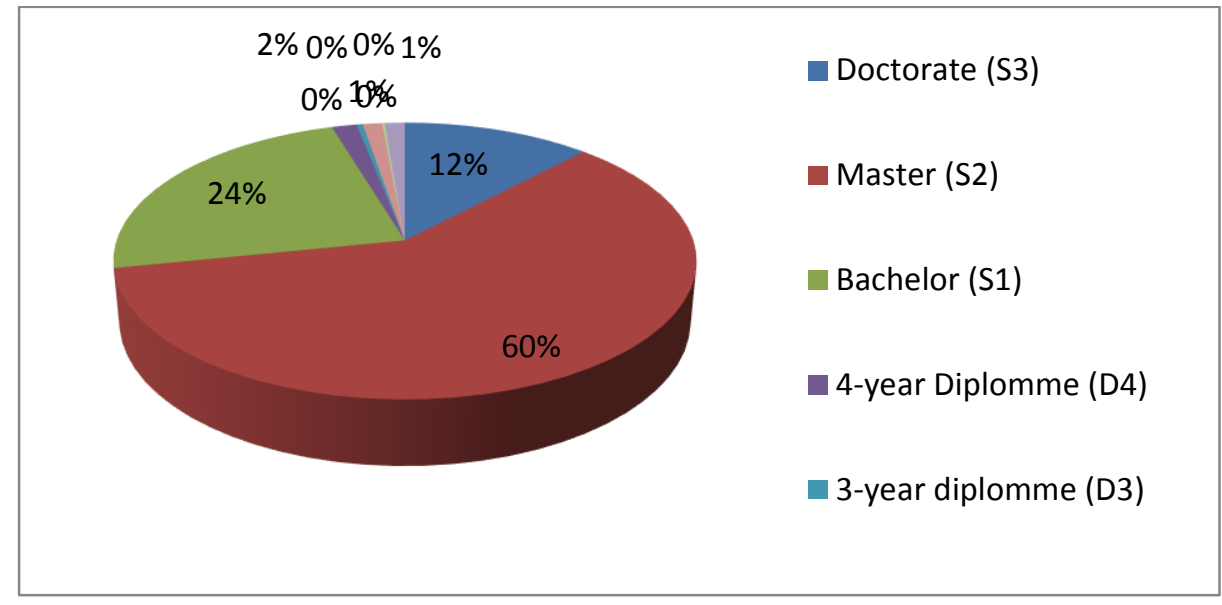

Figure 1 Composition of faculty member based on level of education Source : https://pdpt.dikti.go.id/, accessed June 2014

In general, competency of faculty member can be seen from the status whether they have been professionally certified or not. Regulation of Minister of National Education No. 47 in 2009 stated that to be certified, faculty member have to be assessed in form of portfolio, perceptional assessment by student, colleagues and supervisor, and also self-assessment. The competencies that are assessed includes pedagogic, professionalism, personality, and social competency. The faculty member that have been certified, is considered competent, so that they will received additional pay called benefit of profession. However, the assessment of the certification use very minimum standard of research, even more, there is no specific competency of research that being assessed.

From the phenomenon above, this paper aims to develop the model of research competency for faculty member. This paper will show the analytical process used by author in modeling research competency using preliminary data that have been collected from two faculty members in one faculty of economics and business in Indonesia. This paper is focusing on faculty of economics and business because, based on data in scimagojr.com, for the proportion of research productivity among disciplines in Indonesia, disciplines of Economics, econometrics and finance only produce 125 documents in 2011-2012 and lies in the $18^{\text {th }}$ position among other disciplines, while Business, Management and Accounting field lies in the $19^{\text {th }}$ position with only 116 documents in 2011-2012 out of 24 disciplines. It means that those disciplines needs to be examined more thoroughly, because the problem relatively worse compare to other disciplines. Because those two disciplines traditionally in Indonesia are under Faculty of Economics and Business, so that this research will focus on the Faculty of Economics and Business in Indonesia.

\subsection{THEORETICAL FOUNDATION OF THE STUDY}

\section{Concept of Competency}

Concept of competency influenced by McClelland articles in 1973, and practically given example by his work for United States Information Agency (Spencer \& Spencer,1993; Lucia and Lepsinger,1999). He criticized the traditional academic and aptitude tests that according to him, have failed in predicting job performance or success in life, and were often biased against minorities (Spencer \& spencer,1993). McClelland (in Spencer \& Spencer, 1993) propose the use of criterion samples, who clearly had successful job, and identify the behaviors that causally related to the successful outcomes.

Competency is defined as "an underlying characteristic of an individual that is causally related to criterion-referenced effective and/or superior performance in a job or situation" (Spencer \& Spencer, 1993: 9). It is the way of behaving that is consistently used to achieved desired performance, that differentiate the superior performer with effective performer (Spencer \& Spencer,1993; Dubois \& Rothwell,2004). According to Spencer \& Spencer, effective performance (sometimes called as average by Spencer \& Spencer, 1993 or successful performance by Dubois \& Rothwell,2004) is minimally acceptable level of work. The effective performer successfully meet the standard, but not outstanding (Dubois \& Rothwell,2004). Superior performance (called as exemplary performance Dubois \& Rothwell,2004) defined as one standard deviation above average performance (Spencer \& Spencer,1993). It can be seen as ideal performance or level of performance that be desired in the future but still possible to be achieved in the present time (Dubois \& Rothwell,2004). To prevent ambigue interpretation, in this paper, the term effective (for effective or average) and outstanding (for superior or exemplary) performer will be used.

The discussion of competency concept often fall into debate whether minimum requirement to do the job can be called competency. Most studies agree that competency is the characteristics that lead to superior performance. The minimum requirement for the job, sometimes called as competence (Dubois \& Rothwell,2004), categorized as threshold. It is required to do the job, but can not differentiate superior performer from effective performer.

\section{Competency Modelling}

Before McClelland, psychologist John Flanagan in 1954 have develop techniques called critical incident interview, which attempted to identify critical traits and skills required for successful performance (Lucia and Lepsinger,1999). Nonetheless, the critical incident technique 
restrict only to the observed behavior that is witnessed by the interviewee, it doesn't involve experiences and perceptions of the interviewee (Lucia and Lepsinger,1999). Therefore, McClelland's method followed by most scholars and practitioners to determine competencies, although later many different methods evolved from the original McClelland's (Lucia and Lepsinger,1999).

There are three major approaches used to identify competencies : (i) Modified task analysis approach (MTAA), (ii) Critical trait approach, (iii), Situational approach (Dubois,1993). The MTAA is method that quite similar with task analysis that is the people already familiar with. However, this methods only useful for less abstract jobs (Dubois,1993). The second approach, the critical trait approach is the approach used by McClelland. It is later called The Job competence assessment method (JCAM) (Dubois \& Rothwell,2004) or Behavioral Event Interview (Spencer \& Spencer, 1993). The result of this method is a detailed description of a number of critical incidents on the job which already consider interviewee's thought and feelings (Boyatzis,1982). The third approach has emphasis on the situational context used in developing the competency model, so that it can be acceptable and comfortable to users (Dubois,1993).

The Job Competence Assessment Method (JCAM), becomes the most respected method since it is pioneered by David McClelland him self, that is credited for coining the term "competency". It is also called the classic method (Spencer \& Spencer,1993), that required quite rigid procedure and takes times more than other methods. It is consist of six steps (Spencer \& Spencer,1993) : (i) define performance effectiveness criteria; (ii) identify criterion sample; (iii) collect data; (iv) analyze data (using thematic analysis) and develop the model; (v) validate the model; and (vi) prepare the application of competency model (into HR management function). Although Spencer \& Spencer (1993) gives five alternatives, includes : BEI, panels, survey 360o ratings, expert system database and observation, but behavioral event interview (BEI) considered as the best method to grounded-theoretically generate the competency. According to Dubois and Rothwell (2004), in BEI, the criterion samples be interviewed about critical events in their work experience. The session is taped and later, researcher prepare the verbatim of the interview. From written transcript, the researcher then identify the characteristics revealed during the interview by coding the transcript using qualitative data analytical method (Dubois \& Rothwell,2004).

\section{Research Competency}

Derived from the definition of competency, in this paper, research competency is conceptualized as faculty member's characteristics that lead to outstanding level of research productivity. Research competency of faculty members mostly gained from doctoral education and usually developed in their first employment through mentoring(Byrne \& Keefe,2002). Thus, many literature that discuss about research competency written in the context of academic curriculum, training and assessment. For example, Trierweiler and Stricker (1992) that develop research competency model for the need of training for local clinical scientist (clinical psychology). They emphasized the acquisition of knowledge in their model, as a learning outcome of the training. Similar with Trierweiler and Stricker (1992), Madan-swain,et.al (2012) develop research competency for doctoral level using the cube model or three dimensional framework used to develop the competency model. They devide the competency into two clusters : knowledge-based / foundational competencies and applied / functional competencies. Because the study related to the curriculum for doctoral education, so that the form of competency mostly in form of acquisition of knowledge and skill or apply some particular tasks related to research, not the behavior.

Turan and Sayek (2012) have include ability in their model although in a very basic form, because the context of their study is in undergraduate medical school. However, they also include quite advance competency for undergraduate level such as ability to review journal articles; ability to critique journal articles; ability to compose a manuscript for publication and ability to lead in a research project team. Similar with Turan and Sayek (2012), Adkison and Glaros (2012) also conducted study in the context of undergraduate di medical school They develop competency models as a criteria for assessment. There are three clusters : medical knowledge, interpersonal and communication skills and professionalism with total of six competencies, namely: project understanding, technical skills, attention to details, analytical ability and professionalism, companied by behavior indicators that should be demonstrated by student during education program.

Literature that written in context of faculty member for instance from Harris and Parish (2007) that develop core competencies for family medicine educators. It comprises of seven clusters of competency, and research is one of the clusters. The national Postdoctoral Association (NPA, 2009) of United States (US) develop six core competencies that are meant to serve as both a basis of self-evaluation and a basis for developing training for postdoctoral scholars. So this framework can be called as threshold for postdoctoral scholar. Because postdoctoral training is the most advance training for academic especially as researcher, so we can assume that the framework will be close enough to an ideal competencies of researchers. Faculty of General Dental Practice (UK) (2007) has developed research competencies framework for their faculty. It is usefull to elaborate real context of faculty. The framework consists of five domain : practical skills; problemsolving, thinking and communication skills; personal attitudes and professional ethics; dissemination and roles and functions.

From those literatures, added by competency related to information literacy adopted from Miller (2010), the deductive model of research competency is developed. The competency derived from literature mostly written in task-based approach rather behavior approach, it is because most of literature discuss the model of curriculum that consists of several task that have to be done by the student or is derived from list of assessment criteria of faculty member. The deductive model should be further explored using behavioral event interview to extract the behavior aspect of competency, that have not been revealed, yet. The extracted model will comprise of behaviors that are not possed by the effective performance, only those who are superior performance who have those behavior.

\subsection{METHODOLOGY}

\section{Research Design}

This research adopted procedures suggested by Spencer and Spencer (1993). There are several steps that be conducted in this research, include:

1. Identification of criterion of outstanding performer and effective performer of research of faculty member

2. Identification of who belongs to outstanding performer group and effective performer group

3. Conduct behavioral even interview to extract behavior from each group, based on task list in deductive model.

4. Comparing set of behavior between two group 
5. Extract the set behavior that represent the outstanding performer

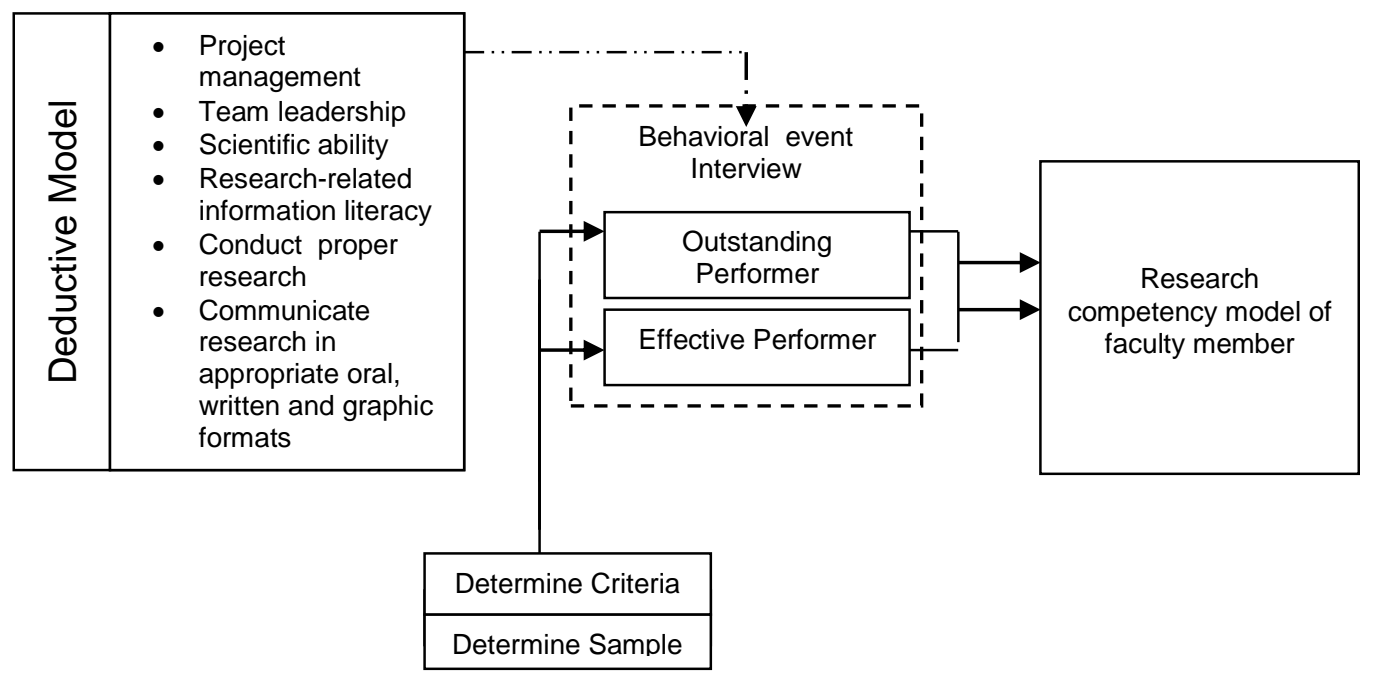

Figure 2 Chart of process the development of research competency model

\section{Participants}

Criterion used in this research to determine those who are effective performer, adopt the criterion of the requirement of Lecturer Work Load demanded by the directorate general of higher education in Indonesia, which is at least publish minimum one research per year (quality of the outlet not be determined, accept for the calculation of credit for rank promotion process). According to Spencer \& Spencer (1993), the outstanding performer is the job incumbent that have value of one standard deviation above the mean, which is 19 to $48 \%$ of output, measure by economic value. Since research output of faculty member in Indonesia can not be directly converted into its economic value, so that it is not applied in this research. Instead, authors tend to agree with what Dubois and Rothwell (2004) say about outstanding performance, that it can be seen as ideal performance, the desired performance in the future that is still possible to achieved in the mean time. This research based on the problem of research productivity, so in author opinion, it is appropriate to take the ideal performance of the researcher as the criterion for the outstanding performance. There are two conditions should be met by outstanding performer in research : quantity of publication and quality. For the quantity aspects, total quantity of publication and the outlets where the article be published, become consideration. For the quality aspect, the citation become the criterion to be considered.

Number of respondents to be interviewed according to Dubois and Rothwell, vary from at least 6 to 12 individual job incumbents for each job be studied. Spencer and Spencer (1993) suggest to use proportion of 4:3 for superior and effective performer. Thus, author aims 7 minimum number of samples. So far, author have interviewed two respondents, 1 for the effective performer, the other considered as outstanding performer. Both respondents come from the same institution, but have different major / discipline.

\subsection{RESULTS AND DISCUSSION}

Each interview was transcribed into verbatim to be analyzed. As suggested by Spencer \& Spencer (1993), each interview is treated as qualitative study, so that to compare all model from each interview, we should use "common language". Competency dictionary from Spencer and Spencer (1993) that consists of 350 behavior indicators, used in this research as those "common language", plus the indicators from deductive model generated by author. So the interview transcript, be coded using the dictionary in the basis of behavior indicators as "the lowest common denominator" (Spencer and Spencer,1993).

For example, when an outstanding performer be asked about how they successfully collaboratein writing papers, especially with foreigner. The interviewee, answered :

I usually work with foreigner professionally, means that the relationship should be mutual. How to achieve equal position with other scientist? We have to identify smartly, what can we offer to them. For example, we know that the person is expert in methodology, and we have data regarding Indonesia (that not all foreigner scientist can access that), we can tell him that he can use my data, "you can do this, do that", and so on. And also in reverse, I think it is obvious the benefit for us, working with the foreigner. So, we have to identify the benefit for them and try to sell it.

From that answer, the analyst noted that it contains :

$\Rightarrow$ Use oral and written communication to express ideas effectively (Col6)

$\Rightarrow$ Offer help and support to other researchers (Col8)

$\Rightarrow$ States confidence in own ability (SCF A.3)

$\Rightarrow$ Calculates the impact of one's action or words (IMP A.4) 
$\Rightarrow \quad$ Makes cost-benefit analyses (ACH A.6)

Lucia and Lepsinger (1999) remind us to avoid some pitfalls such as lacking a consistent interview protocol; seeing what you want to see; if you've seen one, you've seen them all; and relying solely on the incumbent's perception. For example, when the interviewee be asked about what does he think his colleague, subordinate and supervisor see him. The interviewee answered : "I think, they see me as perfectionist". The the interviewer probe," what incidents that might cause you are seen as perfectionist?", then he answered, "I think because quality control. My standard is high, we are developing our reputation, we can not fail the standard, especially deadline. One weakness in our institution that the researchers are not full-timer. They only do research as part-time job, so that they have many reasons to be late to finish their job. So I push them, remind them, tell them what to do. I think that's why I think for my colleague I am perfectionist". From the answer we know that the interviewee does not talk about perfectionist as theoretically defined. Instead, from his explanation we can conclude that he manage the timeline of project (PM3), monitors other's work (CO4), demands high performance (DIR A.4), and creates own measure of excellence (ACH A.3).

The thematic analysis result total 77 appearances of behavior for effective performer and 80 for the outstanding one. It generate 57 and 62 unique behavior for each effective and outstanding performer. The data from thematic analysis then were organized by the importance weight in descending row, based on the frequency of the appearing those such behavior in the interview (Spencer \& Spencer,1993). From this steps, it is revealed that for effective performer, top five competencies are team leadership (most important); project management; achievement orientation; concern for order and quality; and scientific ability (least important), while for outstanding performer, the most important is serve as role model, followed by flexibility, achievement orientation, developing others, and team leadership.

The data then were tabulated to extract the behavior that differentiate outstanding performer from the effective one. In tabulation of data, this research use the procedure proposed by Dubois \& Rothwell (2004). The result of thematic analysis categorize into three set. The first set are those behavior indicators that used by both effective and outstanding performer. This set categorized as threshold, a minimum characteristics required to do the job. The second set, are those that cited by outstanding performer but not by effective performer. This set contain behavioral indicators that differentiate the superior / outstanding performer from the average or effective performer, or what we call as competency. The third set comprise those behavior that only cited by the effective performer. This set should be discarded from the result because they are not used by the outstanding performers even to achieve at minimum requirement (Dubois \& Rothwell,2004).

Table 2 Categorization of data from thematic analysis

\begin{tabular}{|c|c|c|c|}
\hline Competencies & $\begin{array}{c}\text { Effective } \\
\text { performer }\end{array}$ & $\begin{array}{c}\text { Outstanding } \\
\text { performer }\end{array}$ & Category \\
\hline \multicolumn{4}{|l|}{ Team Leadership } \\
\hline Promotes team effectiveness (TL. A.4) & $\mathrm{xxxxx}$ & $\mathrm{xx}$ & Threshold \\
\hline Lead research project team (TL1) & $\mathrm{x}$ & & Discard \\
\hline Motivating others (TL2) & $\mathrm{x}$ & & Discard \\
\hline Uses authority fairly (TL A.3) & $\mathrm{x}$ & & Discard \\
\hline Communicates a compelling vision (TL A.7) & & $\mathrm{xx}$ & Competency \\
\hline Develop research skill of team member (TL3) & & $\mathrm{x}$ & Competency \\
\hline Takes care of the group (TL A.5) & & $\mathrm{x}$ & Competency \\
\hline \multicolumn{4}{|l|}{ Project Management } \\
\hline Conduct project planning (PM1) & $\mathrm{xx}$ & & Discard \\
\hline Establishing priorities (PM2) & $\mathrm{xx}$ & & Discard \\
\hline Manage project timeline (PM3) & & $\mathrm{x}$ & Competency \\
\hline Locates funding sources (PM4) & $\mathrm{x}$ & $\mathrm{x}$ & Threshold \\
\hline Manage personnel needs and deployment (PM5) & $\mathrm{x}$ & $\mathrm{x}$ & Threshold \\
\hline Data and resources management (PM6) & $\mathrm{x}$ & $\mathrm{x}$ & Threshold \\
\hline \multicolumn{4}{|l|}{ Achievement orientation } \\
\hline Creates own measure of excellence (ACH A.3) & $\mathrm{xxx}$ & $\mathrm{xx}$ & Threshold \\
\hline Achievement impact : individual performance only (ACH B.1) & $\mathrm{xx}$ & & Discard \\
\hline Achievement impact : affects a department (ACH B.4) & & $\mathrm{xx}$ & Competency \\
\hline Set challenging goals (ACH A.5) & $\mathrm{x}$ & & Discard \\
\hline Makes cost-benefit analyses (ACH A.6) & & $\mathrm{xxx}$ & Competency \\
\hline \multicolumn{4}{|l|}{ Concern for Order and Quality } \\
\hline Shows a general concern for order and clarity $(\mathrm{CO} 2)$ & $\operatorname{xxxx}$ & & Discard \\
\hline Keeps an organized workspaces (CO 1) & $\mathrm{x}$ & & Discard \\
\hline Monitor others' work (CO 4) & $\mathrm{x}$ & $\mathrm{xx}$ & Threshold \\
\hline $\begin{array}{l}\text { Develops systems (CO 6) } \\
\text { Table } 2 \text { (continued) }\end{array}$ & & $\mathrm{x}$ & Competency \\
\hline \multicolumn{4}{|l|}{ Scientific Ability } \\
\hline Review and critique journals articles (SA4) & $\mathrm{xx}$ & $\mathrm{x}$ & Threshold \\
\hline Formulate a research question (SA1) & $\mathrm{x}$ & $\mathrm{x}$ & Threshold \\
\hline Design hypotheses (SA2) & & $\mathrm{x}$ & Competency \\
\hline Recognize and know when to use primary and secondary resources (SA7) & $\mathrm{x}$ & & Discard \\
\hline $\begin{array}{l}\text { Ability to select, apply, and interpret data-analytic strategies that are the best suited to } \\
\text { the diverse research questions and level of analysis characteristic (SA8) }\end{array}$ & $\mathrm{x}$ & & Discard \\
\hline Contribute to theory within a particular area of study (SA11) & & $\mathrm{x}$ & Competency \\
\hline Analytical Ability (SA12) & $\mathrm{x}$ & & Discard \\
\hline \multicolumn{4}{|l|}{ Collaboration } \\
\hline Participates in professional societies and networks with similar research (Col2) & $\mathrm{x}$ & & Discard \\
\hline Understand research role and expected contribution within team (Col5) & & $\mathrm{x}$ & Competency \\
\hline Use oral and written communication to express ideas effectively (Col6) & $\mathrm{x}$ & $\mathrm{x}$ & Threshold \\
\hline
\end{tabular}




\begin{tabular}{|c|c|c|c|}
\hline Offer help and support to other researchers (Col8) & & $\mathrm{x}$ & Competency \\
\hline Developing rules, expectations, and evaluations for collaborations (Col9) & $\mathrm{x}$ & & Discard \\
\hline Sharing data with collaborators (Col10) & $\mathrm{x}$ & & Discard \\
\hline Ownership and access to data (Col12) & $\mathrm{x}$ & & Discard \\
\hline \multicolumn{4}{|l|}{ Information literacy } \\
\hline Conduct a literature search using electronic resources (IL1) & $\mathrm{x}$ & $\mathrm{x}$ & Threshold \\
\hline Find relevant literature effectively (IL2) & $\mathrm{x}$ & $\mathrm{x}$ & Threshold \\
\hline Read, understand, evaluate, and organize information resources (IL3) & $\mathrm{x}$ & & Discard \\
\hline Incorporated relevant literature into a project (IL4) & $\mathrm{x}$ & & Discard \\
\hline Recognize when information provided is sufficient (IL5) & & $\mathrm{x}$ & Competency \\
\hline Observe and record behavior (IL6) & $\mathrm{x}$ & & Discard \\
\hline \multicolumn{4}{|l|}{ Information seeking } \\
\hline Does research (INF 5) & $\mathrm{xx}$ & & Discard \\
\hline Uses own ongoing systems (INF 6) & $\mathrm{x}$ & $\mathrm{x}$ & Threshold \\
\hline Involves others (INF 7) & $\mathrm{x}$ & & Discard \\
\hline \multicolumn{4}{|l|}{ Conduct Research } \\
\hline Prepares research proposal (CR1) & $\mathrm{x}$ & & Discard \\
\hline Effectively develop a research strategy using the classic planning process (CR2) & $\mathrm{x}$ & & Discard \\
\hline $\begin{array}{l}\text { Efficiently collect, organize and analyze needed qualitative and quantitative data } \\
\text { (CR3) }\end{array}$ & $\mathrm{x}$ & $\mathrm{x}$ & Threshold \\
\hline Know how to modify techniques, if appropriate, for changes in conditions (CR4) & & $\mathrm{x}$ & Competency \\
\hline Perform research ethically (CR5) & $\mathrm{x}$ & & Discard \\
\hline \multicolumn{4}{|l|}{ Communicate research } \\
\hline Present research findings in scientific forum (Com1) & $\mathrm{xx}$ & & Discard \\
\hline Publish in international journals (Com4) & $\mathrm{xx}$ & $\mathrm{x}$ & Threshold \\
\hline \multicolumn{4}{|l|}{ Relationship Building } \\
\hline Makes work-related contacts (RB A.2) & $\mathrm{xxx}$ & $\mathrm{x}$ & Threshold \\
\hline \multicolumn{4}{|l|}{ Directiveness } \\
\hline Gives detailed directions (DIR A.2) & $\mathrm{x}$ & & Discard \\
\hline Speaks assertively (DIR A.3) & $\mathrm{x}$ & & Discard \\
\hline Demands high performance (DIR A.4) & & $\mathrm{x}$ & Competency \\
\hline States consequences of behavior (DIR A.7) & $\mathrm{x}$ & & Discard \\
\hline \multicolumn{4}{|l|}{ Flexibility } \\
\hline Sees situation objectively (FLX A.1) & & $\mathrm{xx}$ & Competency \\
\hline Flexibility applies rules or procedures (FLX A.2) & $\mathrm{xx}$ & $\mathrm{xx}$ & Threshold \\
\hline Adapts tactics to situation or to other's response (FLX A.3) & & $\mathrm{xx}$ & Competency \\
\hline Adapt own strategies, goals or projects to situations (FLX A.4) & $\mathrm{x}$ & $\mathrm{x}$ & Threshold \\
\hline Makes organizational adaptation (FLX A.5) & & $\mathrm{x}$ & Competency \\
\hline \multicolumn{4}{|l|}{ Teamwork and cooperation } \\
\hline Shares information (TW A.2) & $\mathrm{x}$ & & Discard \\
\hline Solicits inputs (TW A.4) & $\mathrm{x}$ & & Discard \\
\hline Empowers others (TW A.5) & $\mathrm{x}$ & $\mathrm{xx}$ & Threshold \\
\hline \multicolumn{4}{|l|}{ Analytical thinking } \\
\hline Break down problems (AT 1) & $\mathrm{x}$ & & Discard \\
\hline Sees multiple relationships (AT A.3) & $\mathrm{x}$ & & Discard \\
\hline \multicolumn{4}{|l|}{ Table 2 (continued) } \\
\hline Makes complex plans or analyses (AT A.4) & & $\mathrm{x}$ & Competency \\
\hline Makes very complex plans or analyses (AT A.5) & & $\mathrm{x}$ & Competency \\
\hline \multicolumn{4}{|l|}{ Publication literacy } \\
\hline Publication literacy & $\mathrm{xx}$ & $\mathrm{x}$ & Threshold \\
\hline \multicolumn{4}{|l|}{ Conceptual thinking } \\
\hline Applies complex concepts (CT A.3) & & $\mathrm{x}$ & Competency \\
\hline Creates new concept (CT A.5) & $\mathrm{x}$ & & Discard \\
\hline \multicolumn{4}{|l|}{ Self-confidence } \\
\hline Presents self forcefully or impressively (SCF A.2) & $\mathrm{x}$ & & Discard \\
\hline States confidence in own ability (SCF A.3) & & $\mathrm{xx}$ & Competency \\
\hline Justifies self-confident claims (SCF A.4) & & $\mathrm{x}$ & Competency \\
\hline Initiative & & & \\
\hline Shows persistence (INT A.1) & $\mathrm{x}$ & & Discard \\
\hline Addresses current opportunities or problem (INT A.2) & & $\mathrm{x}$ & Competency \\
\hline Self-motivation : makes extraordinary efforts (INT B.5) & & $\mathrm{x}$ & Competency \\
\hline Developing others & & & \\
\hline Expresses positive expectations of others (DEV A.1) & $\mathrm{x}$ & & Discard \\
\hline Gives reasons or other support (DEV A.3) & & $\mathrm{x}$ & Competency \\
\hline Reassures and encourages (DEV A.5) & & $\mathrm{x}$ & Competency \\
\hline Does Long-term coaching or training (DEV A.6) & & $\mathrm{xxxx}$ & Competency \\
\hline Delegates fully (DEV A.8) & & $\mathrm{x}$ & Competency \\
\hline Serve as role model & & & \\
\hline $\begin{array}{l}\text { Promote research and scholarly activities within the academic unit, and/o } \\
\text { (Rol1) }\end{array}$ & & $\mathrm{x}$ & Competency \\
\hline
\end{tabular}




\begin{tabular}{|c|c|c|c|}
\hline Teaches research skills to students and faculty (Rol2) & & $\mathrm{xx}$ & Competency \\
\hline Values research in decisions affecting annual reviews and promotion / tenure (Rol3) & & $\mathrm{x}$ & Competency \\
\hline Demonstrate an appreciation of the necessity and value of research (Rol4) & & $\mathrm{xx}$ & Competency \\
\hline Engage and serve the general public (Rol6) & & $\mathrm{xx}$ & Competency \\
\hline $\begin{array}{l}\text { Advance and promote the discipline by participating in public and professional service } \\
\text { activities (Rol7) }\end{array}$ & & $\mathrm{xx}$ & Competency \\
\hline $\begin{array}{l}\text { Advance and promote the discipline by participating in partnerships with government } \\
\text { agencies, foundations, and/or non-profit organizations (Rol8) }\end{array}$ & & $\mathrm{x}$ & Competency \\
\hline Profesionalism (Rol9) & $\mathrm{x}$ & & Discard \\
\hline \multicolumn{4}{|l|}{ Customer service orientation } \\
\hline Takes personal responsibility (CSO A.3) & $\mathrm{x}$ & & Discard \\
\hline Acts to make things better (CSO A.5) & & $\mathrm{x}$ & Competency \\
\hline Addresses underlying needs (CSO A.6) & & $\mathrm{x}$ & Competency \\
\hline
\end{tabular}

The result of this research provide interesting findings. Turns out the outstanding performer tend to shows more people behavior than task behavior. For validation, model that was generated from this research was being compared with other model (Spencer \& Spencer,1993). From their research, Spencer and Spencer generates five generic models, one of them is generic model for professional, includes the researcher as one of jobs that be studied. According to their research, professionals or knowledge workers that identic with technical knowledge-related jobs, who deal primarily with technology and data rather than with person, turn out have one-quarter characteristics related to interpersonal and managerial. Spencer \& Spencer's finding support the findings of this research. The outstanding performer in this research also driven mostly by passion and concern for bigger problems, rather than driven by individual achievement target. It is also consistent with previous study from Fuller in 1999 that cited by Dubois \& Rothwell (2004) that found the passion belongs to outstanding performer.

\subsection{CONCLUSION}

This paper have shown the analytical process of developing research competency model for faculty member using preliminary data that represent two criterion samples, the effective performer and outstanding performer. From the result and discussion, it is revealed that that outstanding performer tend to show more people-focused behavior than task-focused behavior. It is consistent with the previous studies of competency modeling for professional / knowledge workers.

This research has two potential implications. First, from this research we can identify the threshold for research that should have been equipped by each individual researcher. The threshold model will become a good feedback for the curricula of education institution, especially for graduate level. Secondly, the competency model that differentiate the outstanding performer from effective performer, that were generated in this research, can be used by institution to be a guidance in conducting development program and also assessing its faculty member.

As have been explained, that this paper is based on preliminary data that only use two respondents, so that it becomes the flaw of this paper. The result could not be generalized,yet. More samples are needed to validate the findings. The finding also need to be granulated into compact model of competency. It can be helped by conducting validation using other methods, such as Subject Matter Expert Survey / panels or Focus Group Discussion (FGD).

\section{References}

Adkison, L.R. and Glaros A.G. (2012). “Assessing Research Competency in a Medical School Environment”. Medical Science Educator, 22(3S), 139-142

Byrne,M.W.,and Keefe,M.R.(2002).’Building research competence in nursing through mentoring”. Journal of Nursing Scholarship, $34(4)$, 391-396

Dubois,D.D.(1993). Competency-Based Performance Improvement : A Strategy For Organizational Change. HRD Press,Inc

Dubois,D.D., and Rothwell,W.J.(2004). Competency-Based Human Resource Management, Davies-Black Publishing,California

Harris,D.L., Krause,K.C., Parish,D.C., and Smith,M.U.(2007)."Academic Competencies for Medical Faculty". Family Medicine, 39(5), 343

Hesli,V.L., and Lee, J.M. (2011)."Faculty research productivity : why do some of our colleagues publish more than others?", The Profession.

Ju,M.(2010)."The impact of institutional and peer suport on faculty research productivity : a comparative analysis of research vs. Non-research institutions", dissertation, Setton Hall University, paper 1608.

Kotrlik, J., Bartlett, J., Higgins, C. \& Williams, H. (2002). "Factors associated with research productivity of agricultural education faculty". Journal of Agricultural Education, 43(3), 1-10.

Lucia,A.D., and Lepsinger,R.(1999). The Art And Science Of Competency Models, Jossey-Bass/Pfeiffer, A willey company, San Fransisco

Madan-Swain,A., Hankins,S.L., Gilliam,M.B., Ross,K., Reynolds,N., Milby,J., and Schwebel,D.C. (2012),” Applying the Cube Model to Pediatric Psychology: Development of Research Competency Skills at the Doctoral Level". Journal of Pediatric Psychology, 37(2), 136-148

Miller,I.R.(2010)."Turning the tables: a faculty-centered approach to integrating information literacy”. Reference Services Review, 38(4), 647-662

National postdoctoral Association (NPA). (2010), The NPA Postdoctoral Core Competencies [monograph on the internet]. Available from : http://www.nationalpostdoc.org/images/stories/Documents/ToolkitDocuments/Core\%20Competencies\%20-\%2010.02.13.pdf

Soderquist,K.E., Papalexandris,A., Ioannou,G.,and Prastacos,G.(2010).’From task-based to competency-based: A typology and process supporting a critical HRM transition". Personnel Review, 39(3), 325-346

Spencer,Jr., L.M., and Spencer,S.M. (1993). Competence at Work. Wiley, New York

Trierweiler, S. J., and Stricker, G. (1992). "Research and evaluation competency: Training the local clinical scientist", In R. L. Peterson, J. McHolland, R. J. Bent, E. Davis-Russell, G. E. Edwall, E. Magidson, K. Polite, D. L. Singer, and G. Stricker (Eds.). The Core Curriculum In Professional Psychology, 103-113. Washington, D. C.: American Psychological Association and National Council of Schools of Professional Psychology.

Turan, S. and Sayek, İ. (2012)." Scientific Research Competencies for Undergraduate Medical Education: The Case from Turkey”. Medical Science Educator, 22(3S), $190-194$

UK: Faculty of General Dental Practice, The Royal Collage of Surgeons of England. (2007). Research Competencies Framework [monograph on the internet], available from: http://www.fgdp.org.uk/_assets/pdf/research/research\%20competencies.pdf 